\title{
Exchange rate pass-through and inflation targets in Chile
}

\author{
Patricio Mujica and Rodrigo Saens
}

ABSTRACT

\begin{abstract}
Using quarterly data on the Chilean economy from 1986 to 2009, this article looks at the effect of gradual implementation of an inflation-targeting regime on exchange rate passthrough to prices. Initially, the introduction of inflation-targeting contributes to substantial reductions in the pass-through coefficient. However, in the second phase of implementation, once the monetary authority extends the policy horizon and introduces greater flexibility into the exchange rate system, the pass-through coefficient rises sharply. The findings of this study show that exchange rate pass-through to prices, in addition to being sensitive to the inflationary environment, is closely tied to the rules of the game that shape the monetary policy framework.
\end{abstract} pmujica@utalca.cl

Rodrigo Saens is a professor in the Faculty of Economics and Business, University of Talca, Chile. rsaens@utalca.cl 


\section{I}

\section{Introduction}

The theory of purchasing power parity states that any change in the exchange rate brings about a proportional change in price levels. Theoretically and practically, however, the actual magnitude of exchange rate passthrough to prices is determined by a variety of factors, including the pricing power of firms, the degree of economic openness, the composition of imports, the general state of the economy, the inflationary environment and the rules of the game that govern the monetary policy regime.

A number of empirical studies find that exchange rate pass-through to prices not only is partial but also has been falling in nearly every part of the world since the early 1990s. Some studies, such as Dornbusch (1987), suggest that when prices are rigid, they are slow to adjust, which means that pass-through from the exchange rate is incomplete, at least in the short run. Others, such as Goldberg and Knetter (1997) and Burstein, Neves and Rebelo (2003), find that the presence of nontradable inputs and goods, even in open economies, means that exchange rate pass-through to prices will only be partial.

These findings are consistent with those documented by Campa and Goldberg (2005), who, based on a sample of 23 countries in the Organization for Economic Cooperation and Development (OECD), conclude that exchange rate pass-through is incomplete and that differences in the pass-through coefficient between countries mainly reflect differences in types of imports. Their findings also indicate that a substantial part of the observed decline in pass-through coefficients over the past two decades can be explained by a change in the composition of imports, from commodities to manufactured products.

Devereux, Engel and Storgaard (2004) suggest that in monopolistic or oligopolistic industries, where the pricing power of the dominant firms is significant, the magnitude of the pass-through coefficient depends on the currency being used by the foreign firms, or the local distributors, to set prices for their products. According to Bacchetta and Van Wincoop (2005), if the firms wield significant pricing power, exchange rate volatility is an incentive for firms to set prices in foreign currency, increasing the magnitude of exchange rate pass-through to prices. In this context, exchange rate pass-through is determined by the structure of the local market and the degree of exchange rate volatility.

Although exchange rate pass-through could essentially be considered a structural and microeconomic mechanism, empirical evidence shows that it is not a stable parameter over time, nor is it separate from the general state of the economy. According to Goldfajn and Werlang (2000), who examined a panel of 71 developed and emerging economies in the period 1980-1998, the magnitude of pass-through is contingent on the business cycle. Likewise, Winkelried (2003), studying Peru between 1992 and 2002, notes that modifications to the monetary policy regime can have significant repercussions on the relationship between the exchange rate and prices.

A host of empirical studies point to a significant reduction in the magnitude of exchange rate pass-through since the early 1990s. Cunningham and Haldane (1999) document a decline in the pass-through coefficient in the United Kingdom of Great Britain and Northern Ireland and Sweden in 1992, during the depreciation of their respective currencies. McCarthy (2000), in a time series study comparing the periods 1976-1982 and 1983-1998, concludes that pass-through fell by more than $50 \%$ in the United States of America, the United Kingdom, France and Japan.

Taylor (2000) asserts that the pass-through coefficient depends on the willingness of firms to transfer cost increases to consumers. The lower and, above all, the less persistent the inflation rate, the less willing firms, especially import firms, will be to transfer a hike in the nominal exchange rate to prices. If prices are stable and the central bank's commitment is credible, firms have fewer incentives to transfer changes in the exchange rate to prices. The result, in the words of Edwards (2006), is a sort of virtuous circle: lower inflation reduces the pass-through coefficient, and in turn a lower pass-through coefficient reduces inflation.

However, this virtuous circle is not a foregone conclusion. Given that the sensitivity of inflation to fluctuations in the exchange rate depends on the degree and persistence of inflation, the pass-through coefficient may depend on the parameters governing 
the monetary policy regime. Analysing quarterly data for 20 industrialised countries between 1971 and 2003, Gagnon and Ihrig (2004) attribute the reduction in the pass-through coefficient to performance improvements made by central banks in the same period. Based on a larger sample of countries, Frankel, Parsley and Wei (2005) find that the pass-through coefficient is sensitive to a combination of variables associated with both the level of economic development and the orientation of monetary policy. Their findings suggest that the observed decline in the magnitude of the pass-through coefficient reflects, among other factors, changes induced in the macroeconomic environment following the adoption of consistent and credible monetary policies for controlling inflation.

Based on data from 34 countries for 64 quarterly periods from 1989-2004, Mishkin and Schmidt-Hebbel (2007) analyse the impact of the introduction of inflationtargeting on several indicators of macroeconomic performance. Their findings clearly show that in emerging countries, an inflation-targeting regime helps reduce exchange rate pass-through to prices, as well as lowering the inflation rate and moderating the sensitivity of domestic prices to shocks in the price of oil. However, the evidence with respect to industrialised countries is not conclusive.

Drawing on quarterly price indices for tradable and nontradable goods for two industrialised economies and five emerging economies for the period 19852005, Edwards (2006) constructs a comparative time series model to look at how effective the exchange rate is at absorbing external shocks. The study findings indicate that the pass-through coefficient is greater for tradable goods than for nontradable goods, and in both cases it decreases once an inflation-targeting regime is established.

In the case of Chile, studies by Bravo and García (2002), Morandé and Tapia (2002), Noton (2003), De Gregorio and Tokman (2005), Edwards (2006) and Álvarez, Jaramillo and Selaive (2008) provide evidence that the exchange rate pass-through to prices fell during the 1990s. Based on monthly data between January 1986 and December 2001, Bravo and García (2002) estimate that the pass-through of a permanent exchange rate shock does not rise about $20 \%$. Similar results are documented by Morandé and Tapia (2002), who find that the pass-through rate fell from $40 \%$ in the mid-1990s to between $10 \%$ and $15 \%$ in the early 2000s. Noton (2003), in the context of a microeconomic model of oligopolistic competition, shows that the pass-through coefficient is endogenous and started to fall in 1991 from around 20\% to a range between $5 \%$ and $7 \%$. Meanwhile, Edwards (2006) finds that the exchange rate pass-through to prices fell from $21 \%$ to $0.8 \%$ in Chile following the Central Bank's adoption of an inflation-targeting regime in 1994. Lastly, Álvarez, Jaramillo and Selaive (2008), using disaggregated information on import prices, document that long-term pass-through is complete and has not declined over time. In the short term, wholesale prices are more sensitive to exchange rate fluctuations than retail prices, suggesting the presence of nontradable components in the distribution chain.

Most of the evidence documented in these studies corresponds to one period — the 1990s — when Chile's monetary authorities were implementing an inflationtargeting regime. The focus of this article is on assessing the degree to which the exchange rate pass-through coefficient is determined by the parameters governing the monetary policy regime. One aspect specific to the Chilean context, with its heavily indexed economy, is that inflation-targeting was introduced gradually, which makes it possible to distinguish two monetary policy milestones that could have affected the sensitivity of domestic prices to exchange rate fluctuations: the adoption of an inflation-targeting regime, implicitly in 1990 and explicitly in 1994, and the subsequent modifications that were made to it in September 1999 alongside the decision to float the exchange rate.

This study finds that once the first phase of the inflation-targeting regime had been explicitly implemented in Chile, which involved both a specific inflation target and an exchange rate band, the pass-through coefficient fell sharply. In the second phase, however, when the monetary authority floated the exchange rate, widened the target range and lengthened the policy horizon, the sensitivity of internal inflation to fluctuations in the nominal exchange rate increased significantly. Both findings reveal that the coefficient of the exchange rate pass-through to prices depends heavily on the parameters of the monetary policy framework.

This paper is structured as follows. Section II reviews the stylized facts accompanying the decision to adopt an inflation-targeting regime in Chile. The empirical model and analysis of findings are presented in Section III. Lastly, Section IV summarizes the principal conclusions. 


\section{II}

\section{Stylized facts}

Over the past three decades, the elimination of fiscal and monetary imbalances, the quest for stability in the external accounts and the charting of an aggregate spending trajectory compatible with the evolution of potential output have been some of the cornerstones of economic policy in Chile.

Monetary policy has been a key ingredient of the successes of the Chilean economy. As explained by García-Solanes and Torrejón-Flores (2012), the system of inflation targets has served to anchor inflation expectations in Chile, helping to bring down the real inflation rate from nearly $30 \%$ per annum in the late 1980 s to an average of $3 \%$ in recent years.

As illustrated in figures 1 and 2, the Central Bank of Chile adopted a system of inflation targets combined with a system of exchange rate bands in the 1990s. This approach was meant to smooth out fluctuations in the nominal exchange rate and ensure a real exchange rate consistent with the development of the export sector. The midpoint of the band, which was adjusted for the difference between internal and external inflation, was discretely realigned on several occasions owing to presumed changes in the equilibrium real exchange rate.

The decision to adopt a floating exchange rate system in September 1999 was made following various failed attempts to make the inflation-targeting regime compatible with the exchange rate control regime. In fact, the strong capital inflows that characterized the 1990s revealed the limitations of the design of the prevailing monetary policy, with an exchange rate band that had to be adjusted frequently owing to sustained appreciation of the local currency. These adjustments were an implicit acknowledgement of the costs involved in an excessively undervalued local currency, and they introduced an element of uncertainty into the rules of the monetary policy game.

After coping with the initial effects of the Asian crisis, the Central Bank of Chile embarked on a process to gradually expand the exchange rate band in 1998, which culminated in September 1999 with the complete phase-out of the band system and the adoption of a floating exchange rate regime. As explained by Mishkin and Savastano (2001), in order for a monetary policy regime based on an inflation-targeting system to function efficiently, the exchange rate must be allowed to float.

Since September 1999, monetary policy in Chile has been defined by the coexistence of an inflation-targeting system and a floating exchange rate. Although the decision to float the exchange rate and thereby eliminate one of the two nominal anchors was consistent with the monetary policy regime, it coincided with two other changes that

FIGURE 1

Nominal exchange rate and exchange rate band in Chile

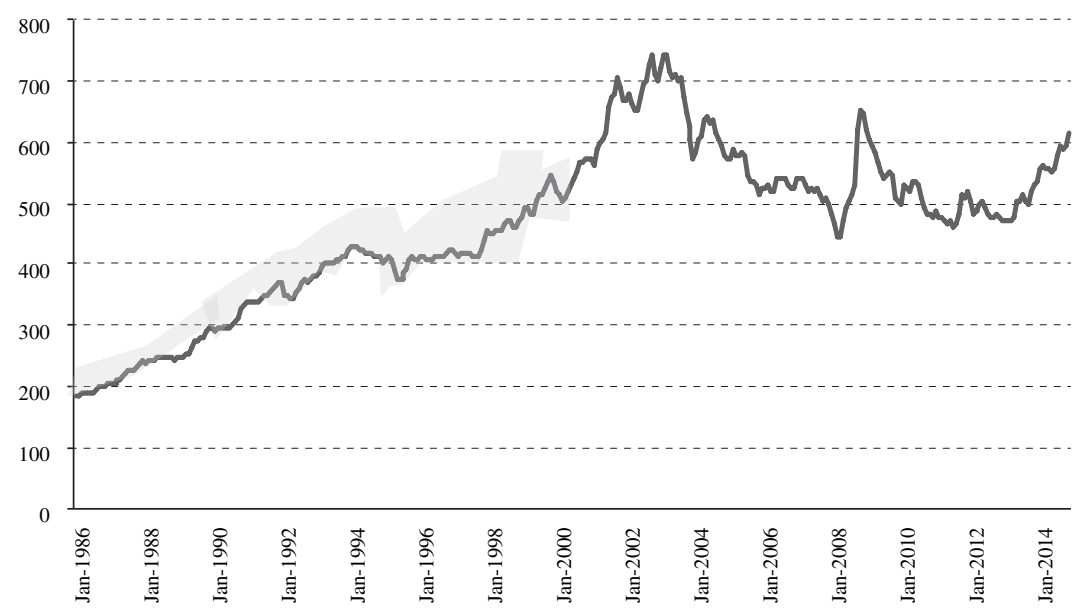

Source: Prepared by the authors, using data from the Central Bank of Chile. 
FIGURE 2

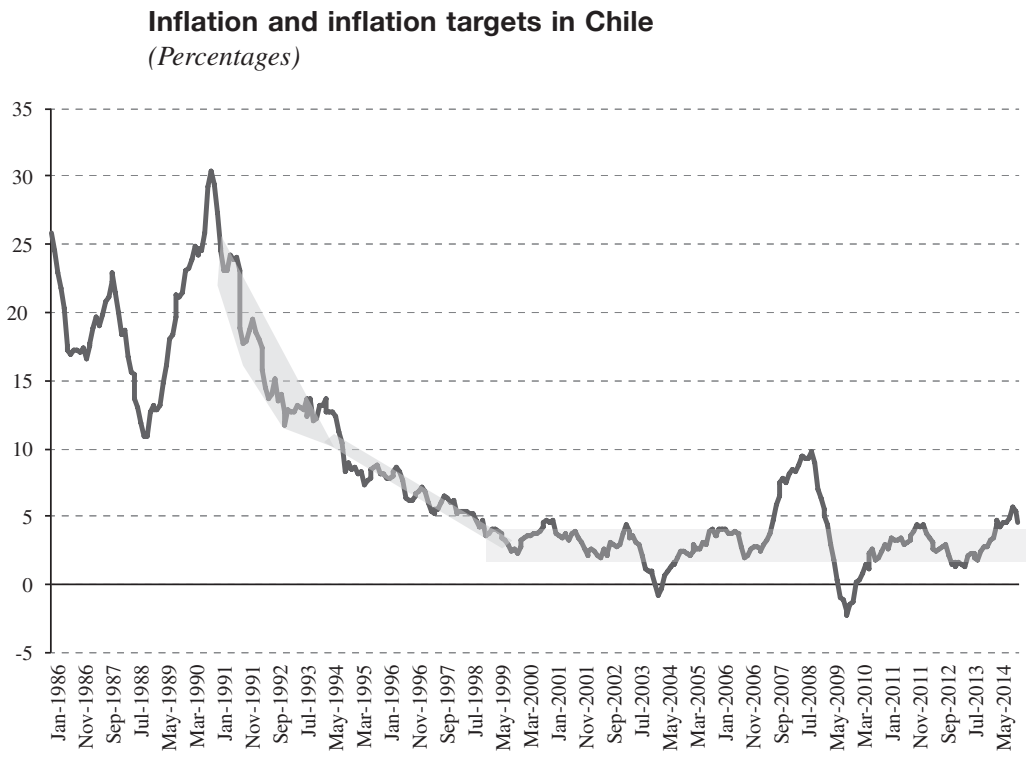

Source: Prepared by the authors, using data from the Central Bank of Chile.

the Central Bank of Chile made to the parameters for inflation-targeting in Chile: a specific 12-month target was discarded in favor of a target range - between $2 \%$ and $4 \%$ - over a 24 -month horizon.

As illustrated in figure 2, the second half of 2001 marked the beginning of a period of greater inflationary volatility, with the inflation rate episodically moving out of the range of tolerance self-imposed by the Central Bank of Chile. In October 2003, inflation fell below the floor of the target range and continued sliding until March 2004, when it hit its lowest level. At that point, it reversed its course and began to rise. In 2007, the inflation rate climbed above the target range, to $7.8 \%$ in December 2007 and 9.9\% in October 2008. Following, however, prices went down again due to a strong contraction in domestic demand triggered by the subprime mortgage crisis, and inflation fell steadily from late 2008. In June 2009 , the rate stood at $1.9 \%$, once again well below the Central Bank's target range.

The question that emerges upon analysing the behaviour of the exchange rate and the inflation rate over the past decade is whether the dual changes that were made in the exchange rate system and the parameters for the inflation-targeting regime governing monetary policy could have altered the transmission mechanism linking fluctuations in the exchange rate with domestic prices in the Chilean economy. Although the changes made monetary policy more flexible, they may also have generated expectations among economic agents that under the new system the Central Bank of Chile would have more room to accommodate the impact on inflation of an appreciation or depreciation in the exchange rate. This shift in expectations was likely reinforced over the past decade by recurrent episodes in which the inflation rate went outside the target range set by the monetary authority.

A simple way of illustrating the evolution of the pass-through coefficient over the past three decades is to run a rolling regression between changes in price levels and changes in the exchange rate. Based on monthly data, a 60-month rolling window and a simple regression between inflation and year-on-year rate of change in the exchange rate, figure 3 offers a first look at the sensitivity of the exchange rate pass-through coefficient to changes in the macroeconomic environment.

The facts illustrated in figure 3 show that in Chile over the past 20 years and especially during the second half of the 1990s, the gradual consolidation of a lowinflation environment has contributed to a substantial reduction in exchange rate pass-through to prices. These same facts, however, indicate that the magnitude of this coefficient is not guaranteed and may depend on risk factors including the set of parameters governing the monetary policy regime. 
FIGURE 3

\section{Exchange rate pass-through (ERPT) to prices}

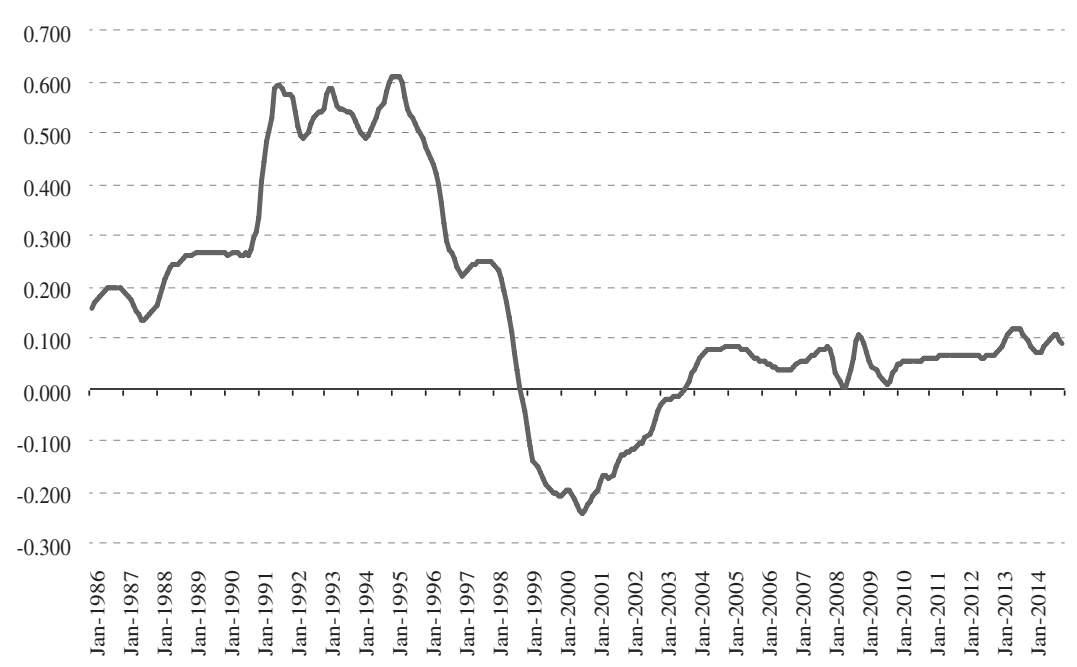

Source: Prepared by the authors, using data from the Central Bank of Chile.

Note: The ERPT 60 corresponds to the exchange rate pass-through coefficient at prices calculated with a simple regression (between inflation and year-on-year variation in the exchange rate) based on a 60 -month rolling window.

\section{III}

\section{Empirical model and results}

The majority of empirical studies on exchange rate pass-through use variations on the following equation:

$$
\Delta \ln p_{t}=\beta_{0}+\beta_{1} \Delta \ln e_{t}+\beta_{2} \Delta \ln p_{t}^{*}+\beta_{3} \Delta \ln p_{t-1}
$$

where $p_{t}$ is the consumer price index (CPI), $e_{t}$ is the nominal exchange rate and $p_{t}{ }^{*}$ is an external price index. Short-term pass-through is expressed as $\beta_{1}$, and longterm pass-through, as $\beta_{1} /\left(1-\beta_{3}\right){ }^{1}$

A number of authors have attempted to determine the effect that adoption of an inflation-targeting system has on the pass-through coefficient, by running the following type of equation:

$$
\begin{gathered}
\Delta \ln p_{t}=\beta_{0}+\left(\beta_{1}+\beta_{4} D_{1}\right) \Delta \ln e_{t} \\
+\beta_{2} \Delta \ln p_{t}^{*}+\left(\beta_{3}+\beta_{5} D_{1}\right) \Delta \ln p_{t-1}
\end{gathered}
$$

\footnotetext{
1 Despite its compelling simplicity, as noted in Meese and Rogoff (1983), equation (1) has a potential problem of endogeneity, the principle being that variations in the exchange rate in equation (1) could be correlated with the error term-which is assumed to satisfy the necessary condition to use the ordinary least squares (OLS) method.
}

where $D_{1}$ has a value of 1 for the period following adoption of the inflation-targeting regime and a value of 0 for the rest of the sample. After adoption of the inflation target, short-term pass-through in equation (2) is expressed as the sum of the coefficients $\beta_{1}$ and $\beta_{4}$. If the inflation-targeting regime decreases pass-through, the coefficient $\beta_{4}$ should be statistically significant and negative.

In models such as the one expressed in equation (2), it is generally permissible for the coefficient on the lagged inflation rate in the period prior to the structural break to be different from the one estimated for the subsequent period, the purpose being to look at whether a stronger (weaker) commitment by the monetary authority to an inflation target reduces (increases) inflation inertia. As noted by Edwards (2006), a reduction in inertia provides an alternate channel for reducing long-term pass-through. Given that long-term pass-through following the adoption of an inflation-targeting regime is expressed as $\left(\beta_{1}+\beta_{4}\right) /\left[1-\left(\beta_{3}+\beta_{5}\right)\right]$, the smaller that $\beta_{3}$ and $\beta_{5}$ are, i.e. the lower the inflation inertia, the lower the rate of long-term pass-through of changes in the exchange rate will be to changes in price levels. 
Empirically, the model used in this study, expressed in equation (3), adds a second dichotomous variable, $D_{2}$, whose coefficient is intended to measure whether the magnitude of pass-through was or was not affected by two events that may have altered the effectiveness of monetary policy in Chile, namely: (i) liberalization of the exchange rate regime; and (ii) modification of the parameters governing the inflation-targeting regime, or both.

$$
\begin{gathered}
\Delta \ln _{t}=\beta_{0}+\left(\beta_{1}+\beta_{4} D_{1}+\beta_{6} D_{2}\right) \Delta \ln e_{t}+\beta_{2} \Delta \ln p_{t}^{*} \\
+\left(\beta_{3}+\beta_{5} D_{1}+\beta_{7} D_{2}\right) \Delta \ln p_{t-1}+\beta_{8} \Delta \operatorname{lngap} t
\end{gathered}
$$

If liberalizing the exchange rate or relaxing inflation-targeting, or both, increase (decrease) passthrough, the $\beta_{6}$ coefficient should be statistically significant and positive (negative). In order to control for domestic inflationary pressures, the right side of equation (3) includes the variable gap, indicating the excess of domestic expenditure growth over output growth.

\section{Stationary tests}

To analyze whether the series used in the model are stationary or not, two tests were run: (i) the augmented Dickey-Fuller test; and (ii) the Phillips-Perron unit root test. To control for serial autocorrelation of the error, application of the augmented Dickey-Fuller test included lagged coefficients for the variable $x_{i}$ :

$$
\Delta x_{t}=\beta_{1}+\beta_{2} t+\lambda x_{t-1}+\alpha_{i} \sum_{i=1}^{N} \Delta x_{t-i}+\varepsilon_{t}
$$

where $\varepsilon_{\mathrm{t}}$ is the random term ("white noise"), which is assumed to follow a normal distribution. To detect the existence of the unit root, the null hypothesis $\mathrm{H}_{0}: \lambda=0$ is tested. Zivot and Andrews (1992) and Vogelsang and Perron (1998) show that when the series is not stationary, the traditional $t$-student unit root values are not applicable, i.e., the significance of the coefficient obtained using the ordinary least squares (OLS) method follows a nonstandard distribution, so the statistic $\tau$ from the Dickey-Fuller test should be used.

Through the Phillips-Perron test, complementary to the augmented Dickey-Fuller test, the same parameter $\lambda=0$ is evaluated, but unlike in the former, the serial autocorrelation of the error is not controlled using lagged coefficients of $x_{t}$, but rather through direct correlation of the same $t$-student statistic.

The unit root tests for each one of the series used in this study are presented in table 1 . The results show that the domestic inflation, external inflation and exchange rate variation series are stationary.

\begin{tabular}{|c|c|c|c|c|}
\hline & \multicolumn{2}{|c|}{ Augmented Dickey-Fuller } & \multicolumn{2}{|c|}{ Phillips-Perron } \\
\hline & $\mathrm{ADF}$ & Critical value to $5 \%$ & $\mathrm{PP}$ & Critical value to $5 \%$ \\
\hline Percentage change in the exchange rate & -7.33 & -3.45 & -6.93 & -3.45 \\
\hline External inflation & -4.09 & -3.45 & -6.88 & -3.45 \\
\hline
\end{tabular}

TABLE 1

Dickey-Fuller (ADF) and Phillips-Perron (PP) unit root tests ${ }^{a}$

Source: Prepared by the authors.

a All tests were run using a constant and a trend.

\section{Structural change test}

For estimation of the proposed model, two monetary policy events must be identified that have proven to affect the magnitude of exchange rate passthrough to price levels: (i) the adoption of an inflation target; and (ii) the modification of the exchange rate regime and of parameters governing the inflationtargeting regime.
Figure 4 illustrates the evolution of the F-statistic in Chow's test for the base specification of the model: domestic inflation as a function of the rate of change in the price of the dollar, external inflation and lagged domestic inflation for one period. The null hypothesis of Chow's test is that there is no structural change. The results indicate that the highest probability of a break came in the first quarter of 1994, that is, close to the date on which the Central Bank of Chile made a firm commitment to the inflation-targeting regime. 
FIGURE 4

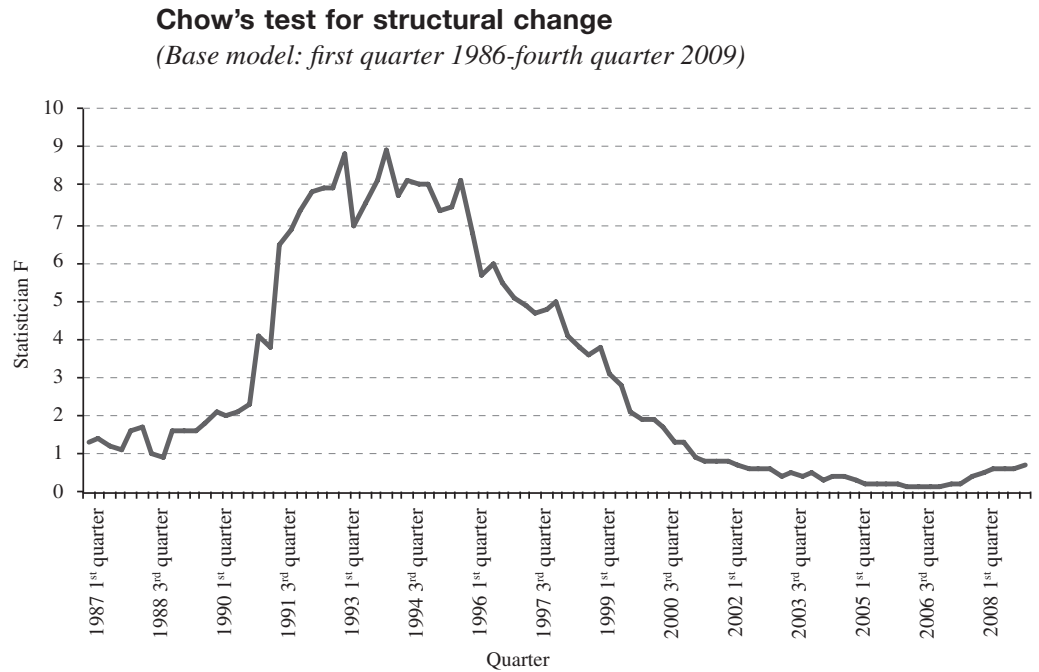

Source: Prepared by the authors, using data from the Central Bank of Chile.

\section{Estimation of the model}

To analyse exchange rate pass-through to price levels, this study estimates three specifications of equation (3). The first looks at domestic inflation as a function of the percentage change in the nominal exchange rate, external inflation, the excess of domestic expenditure growth over output growth (gap) and a multiplicative dichotomous variable $\left(D_{1}\right)$ that shows the effect on pass-through of the adoption of inflation targets. The third quarter of 1994 was selected because that period coincided with the Central Bank of Chile's decision to adopt a specific inflation target, and as demonstrated by Chow's test in figure 4 , the probability of structural change hit a peak around that quarter.

The $D_{2}$ coefficient in specification 2 measures the effect on pass-through of the decision to change the inflation-targeting regime - from a specific 12-month target to a 24-month target range of between $2 \%$ and $4 \%$ - in a contest of exchange rate liberalization. In order to corroborate the results, a third specification was estimated using the same data as in the first two specifications. However, specification 3 used only the period subsequent to the adoption of inflation targets, that is, from the first quarter of 1994 to the fourth quarter of 2009.

The data used come from the quarterly series published by the Central Bank of Chile and correspond to the consumer price index $(p)$, the consumer price index in the United States of America $\left(p^{*}\right)$ and the observed exchange rate $(e)$ for the period running from the first quarter of 1986 to the fourth quarter of 2009. The excess of domestic expenditure growth over output growth (gap) is calculated using the series for private consumption, government consumption, gross fixed capital formation (GFCF) and gross domestic product (GDP) for the same period. For the percentage variation, the change in the natural logarithm of the quarterly average for each variable was used.

The results obtained are presented in table 2 . The three estimated specifications show statistically significant coefficients for the pass-through, trending as expected and of a magnitude in the range of findings reported by Gagnon and Ihrig (2004), Campa and Goldberg (2005) and Edwards (2006). In specification 1, in the period preceding the fourth quarter of 1994, the short-term pass-through coefficient is 0.17 , and the long-term pass-through coefficient is 0.48 .

The estimates reported in table 2 also show that the adoption of inflation targets reduces the degree of inflation inertia. Whereas in the period prior to the fourth quarter of 1994 , the inertia coefficient is 0.65 , in the period after that quarter, it falls to 0.50 .

In the two specifications ( 1 and 2 ) of equation (3), the estimated coefficient for the dichotomous variable $D_{1}$, which multiplies the pass-through coefficient, is negative and statistically significant. As noted by Taylor (2000) and Winkelried (2003), if economic agents understand and believe in the monetary authority's commitment to price stability, then pass-through will diminish following the adoption of an inflation-targeting regime. Once the Central Bank of Chile committed to a specific target in June 1994, the coefficient for exchange rate pass-through to domestic inflation fell, from 0.17 to 0.04 in the short 
run and from 0.48 to 0.11 in the long run. These outcomes are consistent with those reported by Gagnon and Ihrig (2004), Frankel, Parsley and Wei (2005), Edwards (2006) and Mishkin and Schmidt-Hebbel (2007): exchange rate pass-through to prices diminishes significantly in countries that adopt an inflation-targeting regime.

The results in table 2 also show that the changes that were made to the inflation-targeting regime in Chile, which became fully operational in December 2000 and were implemented in conjunction with liberalization of the exchange rate, brought about a sizeable increase in the pass-through coefficient. As Taylor (2000) asserts, if exchange rate pass-through to prices depends on inflationary performance, any decrease in the pass-through coefficient could potentially be eliminated by a reversal of conditions in the macroeconomic environment, e.g., due to a change in the parameters for the targeting regime that orients monetary policy. The results reported for specification 3 in table 2 corroborate this: after the first quarter in 2001, the pass-through coefficient rises by a statistically significant margin, 13 and 48 percentage points in the short and long terms, respectively.

TABLE 2

Exchange rate pass-through to prices ${ }^{a}$

\begin{tabular}{|c|c|c|c|}
\hline & Specification 1 & Specification 2 & Specification 3 \\
\hline Constant & $\begin{array}{r}0.000 \\
(0.59)\end{array}$ & $\begin{array}{r}0.002 \\
(0.93)\end{array}$ & $\begin{array}{l}-0.000 \\
(-0.17)\end{array}$ \\
\hline Percentage $\Delta$ in exchange rate & $\begin{array}{r}0.167 \\
(3.12)\end{array}$ & $\begin{array}{r}0.167 \\
(3.10)\end{array}$ & $\begin{array}{l}-0.070 \\
(-2.93)\end{array}$ \\
\hline External inflation & $\begin{array}{c}0.703 \\
(6.17)\end{array}$ & $\begin{array}{c}0.698 \\
(6.74)\end{array}$ & $\begin{array}{c}0.644 \\
(9.76)\end{array}$ \\
\hline gap & $\begin{array}{r}0.127 \\
(4.83)\end{array}$ & $\begin{array}{r}0.125 \\
(4.77)\end{array}$ & $\begin{array}{r}0.087 \\
(6.34)\end{array}$ \\
\hline Domestic inflation $(-1)$ & $\begin{array}{c}0.649 \\
(7.88)\end{array}$ & $\begin{array}{c}0.638 \\
(7.62)\end{array}$ & $\begin{array}{l}0.738 \\
(9.43)\end{array}$ \\
\hline D1* Percentage $\Delta$ in exchange rate & $\begin{array}{l}-0.128 \\
(-2.21)\end{array}$ & $\begin{array}{r}-0.227 \\
(-3.33)\end{array}$ & \\
\hline D1* Domestic inflation $(-1)$ & $\begin{array}{l}-0.145 \\
(-1.99)\end{array}$ & $\begin{array}{l}-0.077 \\
(-0.86)\end{array}$ & \\
\hline D2* Percentage $\Delta$ in exchange rate & & $\begin{array}{c}0.122 \\
(2.81)\end{array}$ & $\begin{array}{r}0.127 \\
(4.35)\end{array}$ \\
\hline D2* Domestic inflation $(-1)$ & & $\begin{array}{l}-0.130 \\
(-1.36) \\
\end{array}$ & $\begin{array}{l}-0.216 \\
(-2.26) \\
\end{array}$ \\
\hline $\begin{array}{l}\text { Adjusted } R^{2} \\
\text { No. of observations }\end{array}$ & $\begin{array}{l}0.75 \\
95\end{array}$ & $\begin{array}{l}0.76 \\
95\end{array}$ & $\begin{array}{l}0.67 \\
60\end{array}$ \\
\hline
\end{tabular}

Source: Prepared by the authors.

a All models were estimated using errors robust to autocorrelation and heteroskedasticity (Newey-West method).

\section{IV}

\section{Summary and conclusions}

The purpose of this study is to evaluate the effect in Chile of the gradual implementation of an inflation-targeting regime on exchange rate pass-through to prices. The main hypothesis is that changes in the monetary policy regime significantly alter the relationship between exchange rate and prices. It should be noted that the exchange rate pass-through coefficient, as well as other macroeconomic risk factors, is specifically tied to the parameters that shape the monetary policy framework.
In line with the findings of Edwards (2006), Mishkin and Schmidt-Hebbel (2007) and Mishkin (2008), the results documented in this paper confirm that the adoption of an inflation-targeting regime in Chile, through the gradual consolidation of a low-inflation environment, has contributed to a substantial reduction in exchange rate pass-through to prices.

However, this virtuous circle (lower inflation reduces the pass-through coefficient, and in turn a 
lower pass-through coefficient reduces inflation) is not a foregone conclusion. As revealed by the findings of this study, exchange rate pass-through to prices, in addition to being sensitive to the inflationary environment, is strongly tied to the parameters that shape the monetary policy regime.

\section{Bibliography}

Álvarez, R., P. Jaramillo and J. Selaive (2008), "Exchange rate passthrough into import prices: the case of Chile", Working Papers, No. 465, Santiago, Central Bank of Chile.

Bacchetta, P. and E. van Wincoop (2005), "A theory of the currency denomination of international trade", Journal of International Economics, vol. 67, No. 2, Amsterdam, Elsevier.

Bravo, H. and C. García (2002), "Medición de la política monetaria y el traspaso (pass-through) en Chile", Economía Chilena, vol. 5, No. 3, Santiago, Central Bank of Chile.

Burstein, A., J. Neves and S. Rebelo (2003), "Distribution costs and real exchange rate dynamics during exchange rate-based stabilizations", Journal of Monetary Economics, vol. 50, No. 6, Amsterdam, Elsevier.

Campa, J. and L. Goldberg (2005), "Exchange rate pass-through into import prices", The Review of Economics and Statistics, vol. 87, No. 4, Cambridge, Massachusetts, The MIT Press.

Cunningham, A. and A. Haldane (1999), "The Monetary Transmission Mechanism in the United Kingdom: Pass-Through and Policy Rules", Bank of England.

De Gregorio, J. and A. Tokman (2005), "El miedo a flotar y la política cambiaria en Chile", Economía Chilena, vol. 8, No. 3, Santiago, Central Bank of Chile.

Devereux, M., C. Engel and P. Storgaard (2004), "Endogenous exchange rate pass-through when nominal prices are set in advance", Journal of International Economics, vol. 63, No. 2, Amsterdam, Elsevier.

Dornbusch, R. (1987), "Exchange rates and prices", American Economic Review, vol. 77, No. 1, Nashville, Tennessee, American Economic Association.

Edwards, S. (2006), "The relationship between exchange rates and inflation targeting revisited", NBER Working Paper, No. 12163, Cambridge, Massachusetts, National Bureau of Economic Research.

Frankel, J., D. Parsley and S. Wei (2005), "Slow pass-through around the world: a new import for developing countries?", NBER Working Paper, No. 11199, Cambridge, Massachusetts, National Bureau of Economic Research.

Fuentes, M. (2007), "Pass-through to import prices: evidence from developing countries", Working Papers, No. 320, Santiago, Institute of Economics, Catholic University of Chile.

Gagnon, J. and J. Ihrig (2004), "Monetary policy and exchange rate pass-through", International Journal of Finance and Economics, vol. 9 , No. 4, Wiley.
García-Solanes, J. and F. Torrejón-Flores (2012), "Inflation targeting works well in Latin America", CEPAL Review, No. 106 (LC/G.2518-P), Santiago.

Goldberg, P. and M. Knetter (1997), "Goods prices and exchange rates: what have we learned?", Journal of Economic Literature, vol. 35, No. 3, Nashville, Tennessee, American Economic Association.

Goldfajn, I. and S. Werlang (2000), "The pass-through from depreciation to inflation: a panel study", Working Paper, No. 5, Central Bank of Brazil.

McCarthy, J. (2000), "Pass-through of exchange rates and import prices to domestic inflation in some industrialized economies", Staff Report, No. 111, New York, Federal Reserve Bank of New York.

Meese, R. and K. Rogoff (1983), "Empirical exchange rate models of the seventies: do they fit out of sample?", Journal of International Economics, vol. 14, No. 1-2, Amsterdam, Elsevier.

Mishkin, F. (2008), "Exchange rate pass-through and monetary policy", NBER Working Paper, No. 13889, Cambridge, Massachusetts, National Bureau of Economic Research.

Mishkin, F. and M. Savastano (2001), "Monetary policy strategies for Latin America", Journal of Development Economics, vol. 66, No. 2, Amsterdam, Elsevier.

Mishkin, F. and K. Schmidt-Hebbel (2007), "Does inflation targeting make a difference?", NBER Working Paper, No. 12876, Cambridge, Massachusetts, National Bureau of Economic Research.

Morandé, F. and M. Tapia (2002), "Exchange rate policy in Chile: from the band to floating and beyond", Working Papers, No. 152, Santiago, Central Bank of Chile.

Noton, C. (2003), "The pass-through from depreciation to inflation: Chile 1986-2001", Estudios de Economía, vol. 30, No. 1, Santiago, University of Chile.

Taylor, J. (2000), "Low inflation. Pass-through and the pricing power of firms", European Economic Review, vol. 44, No. 7, Amsterdam, Elsevier.

Vogelsang, T. and P. Perron (1998), "Additional tests for a unit root allowing for a break in the trend function at an unknown time", International Economic Review, vol. 39, No. 4, Wiley.

Winkelried, D. (2003), “¿Es asimétrico el pass-through en el Perú? Un análisis agregado", Revista Estudios Económicos, No. 10, Lima, Central Reserve Bank of Peru.

Zivot, E. and D. Andrews (1992), "Further evidence on the great crash, the oil-price shock, and the unit-root hypothesis", Journal of Business \& Economic Statistics, vol. 10, No. 3, American Statistical Association. 